\title{
Exploring a Model of Whistle Blowing System for Malaysian Municipal Council
}

\author{
Maheran Zakaria ${ }^{1}$, Rahayu Abdul Rahman ${ }^{2} \&$ Hasnun Anip Bustaman ${ }^{3}$ \\ ${ }^{1}$ Faculty of Accountancy, Universiti Teknologi MARA Kelantan, Bukit Ilmu, Machang, Kelantan, Malaysia \\ ${ }^{2}$ Faculty of Accountancy, Universiti Teknologi MARA Perak, Tapah Campus, Tapah, Perak, Malaysia \\ ${ }^{3}$ Faculty of Business Management, Universiti Teknologi MARA Kelantan, Bukit Ilmu, Machang, Kelantan, \\ Malaysia \\ Correspondence: Maheran Zakaria, Faculty of Accountancy, Universiti Teknologi MARA Kelantan, Bukit Ilmu, \\ 18500 Machang, Kelantan, Malaysia. E-mail: maheranzakaria@gmail.com
}

Received: March 16, 2020

Accepted: April 30, 2020

Online Published: June 29, 2020

doi:10.5430/ijfr.v11n3p62

URL: https://doi.org/10.5430/ijfr.v11n3p62

\begin{abstract}
A municipal council is one of the local authorities established under the auspice of Malaysian local government. The objective is to deliver services to a community under its jurisdiction in a sustainable manner, but evidences indicated that the service qualities have deteriorated due to numerous malpractices. The malpractices could be prevented should any of the insiders who witness the incidences whistle blow to those who have power to act. However, not many are willing to report for fear of reprisal, retaliation and even life threatening. Despite that a whistleblowing system is established to encourage whistleblowing, such system has yet to be formed in any of Malaysian municipal councils. Intrigued with the issue, the objective of this study is to explore a model of whistle blowing system for a Malaysian municipal council. A hermeneutic phenomenography study was conducted in which data were gathered through in-depth interviews and focus group discussions. The participants consisted of four top management and sixty officials from a Malaysian municipal council. Data were analyzed qualitatively using Nvivo 14 and triangulated with other source of documents. The findings from emergent themes proposed a model of the whistleblowing system that consisted of four elements namely protection, internal control policies, incentives and ethical culture. This discovery provides useful insights to policy makers, relevant authorities, and academic fraternities of the model of whistle blowing system that will alleviate malpractices and thus elevate the transparency, efficiency and integrity of the municipal council to the fullest.
\end{abstract}

Keywords: whistle blowing, system, model, malpractices, municipal council

\section{Introduction}

Malaysian government system is manifested by three tiers namely Federal, State and Local. The local government is the lowest tier with four types of councils under its purview that are city, municipal, district and special or modified. The councils are classified based on two criteria; number of serving resident and total annual income. Generally, a municipal status would be granted for a council that serves a community of more than 150,000 residents and earns an income of not less than RM 20 million per annum.

A municipal council is empowered to set up its own local projects and standards for the community that it serves, if it does not contravene any national legislation. The objective of the council is to deliver services in the interests of all stakeholders. Specifically, the interest of residents who are paying municipal taxes and services charges is in the expectation that the essential infrastructure will be delivered and maintained in a sustainable manner. Indeed, with good governance and proper financial management, the municipal council is expected to render the best service and advertently promote social and economic development of the residents under its jurisdiction.

However, according to Haltzheusen (2016), a municipal council is more susceptible to malpractices because in a small community, the relationship between the individual resident and officials happens at greater levels of intimacy. Frequent meetings are more likely to ensue between both parties and commonly occur at more decentralized levels. This situation would more likely ignite various kinds of malpractices such as bribery, extortion, embezzlement, 
nepotism and graft. Hence, this might deteriorate the quality of service delivery and thus depart from its ultimate objective of delivering the best service to the betterment of the community.

Many evidences have indicated that municipal councils throughout the globe were intertwined with malpractices. Among others are the downfalls of South African municipal councils which were due to financial malpractices that caused massive losses to the nation (Municipal Financial Sustainability Index (MFSI) for 2018). Councilors in Somalia were unable to uplift the residents' well-being, which had stunted their social and economic growth (Ahmed \& Koech, 2019). Malaysia is not spared either since it was found that many transactions were passed by the councilors without the knowledge or consent from those of higher authority. Apart from that, there were incidences that the councilors awarded contracts either to themselves or persons who pay them with large bribe (Star online, 17 June 2015).

According to Chamunorva (2015), a public office, specifically a municipal council, is at high risk of malpractices and most often, its officials are the first who witness the incidences. Indeed, it is a duty of public officials to disclose and report the incidences in order to protect organization from potential harm and destruction. The disclosure of illegal, immoral or illegitimate practices by the officials who are under the control of their employers, to people or organizations with the power to act is known as whistle blowing (Near \& Miceli, 1995).

Whistleblowing is an effective way of uncovering malpractices, including those which are hardly detected during routine audit (PwC, 2014). For example, in the case of Worldcom, Tyco and Enron, a whistleblower was the one who highlighted the malpractices. Additionally, the Malaysian financial scandal of 1Malaysian Development Berhad (MDB) that costs the government to suffer USD10 billion of losses (Star Online, 18 December 2018) was also highlighted by a whistleblower.

To whistle blow is not an easy task as it needs courage, integrity and moral evaluation in which one must put the interest of the public ahead than of its own. Despite that, many honour a whistleblower as a savior or hero but many also condemn him as malcontent, traitor, troublemaker and misfit for exposing malpractices of his superiors or colleagues. Those who oppose believe that an employee should have prima facie duty of loyalty to his organisation and should not whistle blow as it will tarnish the organizational image and reputation. Indeed, Malaysian Official Secrecy Act (1972) also prohibits public officials from disclosing internal information to outsiders.

Although Whistle Blowing Protection Act 2010 (Act 711) was established to offer protection, it only confines to those who whistle blow to seven external audiences namely Royal Malaysian Police, Royal Malaysian Custom Department, Immigration Department, Malaysian Anti-Corruption Commission, Road Transport Department, Companies Commission of Malaysia and Securities Commission. No protection is offered to internal whistleblowers thus far. Without protection, many are reluctant to whistle blow for fear of reprisals, losing job and social life, isolation and even life threatening.

Despite many opine that a whistleblowing system will incite employees to whistle-blow, not many organisations have whistleblowing system in place (PwC Global Economic Crime Survey 2014). Even worse, scarce or no whistleblowing system has been implemented in public institutions, specifically in Malaysian municipal council. In the absence of the whistleblowing system, officials may perceive that management is not serious in fighting malpractices and thus shun from whistleblowing.

To date, whistleblowing has sparked the interests of many studies, most are in the context of employees (Alleyne et al., 2015; Bjorkelo et al., 2010; Leong, 2017; Magnus-Mesher \& Viswesvaran, 2005; Zakaria et al., 2017), accountants (Seifert et al., 2010) and auditors (Syed Mohd, 2014) in the private institutions. Additionally, most of the prior studies were conducted in a quantitative approach. As far as the researchers are concerned, dearth of study has been conducted to examine whistleblowing in the context of municipal council. To fill this gap, the objective of this study is to carry out a study in a Malaysian municipal council by exploring a model of the whistle blowing system in a qualitative approach.

The study starts with the introduction and followed by reviewing literature of prior studies. Next, it describes on methodology adopted for this study. Then, it is followed with the discussion by offering implication to management and academics. Finally, it ends up with a conclusion.

\section{Literature Review}

\subsection{Malpractices in Municipal Council}

Malpractices in municipal council are manifested in many forms, among others are bribery, nepotism, transactions executed without oversight approval from higher levels of government, offering tenders to cronies and disciplinary 
issues among officials (Ahmed \& Kenyatta, 2019). The malpractices are entrenched symptoms of poor governance that adversely affects revenues, service delivery, public confidence and trust. Hence, it is important for the municipal councils to develop a culture which will pave the way for the emergence of not only being dedicated, efficient and ethical public service but also emphasize on the duty of public officials to report or whistle blow, if they stumble upon any malpractice when performing their duties.

\subsection{Internal and External Whistleblowing}

Internal whistleblowing refers to reporting of malpractices to those who are in the higher hierarchy inside the institutions (Near \& Micelli, 2013). External whistleblowing, on the other hand, refers to reporting of malpractices to those who are outside the organisations. Employees favor to whistle blow internally instead of externally as the former is less risky than the later (Richardson et al, 2012) and is also detrimental to them and organisations (Miller, 2015). However, internal whistleblowing is not a widely accepted behaviour (Fulcrum, 2012) because the management may not like employees to disclose the incriminated information.

External whistle blowing may lead to public embarrassment, government scrutiny, hefty fines and litigation (Holtzhausen, 2016) as it does not only expose the internal malpractices but also an organisation that fails to stop and correct malpractices by itself. According to Zakaria et al. (2017), most of the employees tend to blow the whistle internally, however, if they find that internal audiences are of complicit with the malpractices, they look for external audiences who are able to intercede. Ironically, a potential whistleblower would evaluate the difficulties and opportunities before whistle blowing either to internal or external audiences.

Having a whistleblowing system in place, will encourage employees to whistle blow within an organization. This can avoid external whistleblowing which is extremely costly and demeaning (Pitroff, 2013). Hence, internal whistleblowing would save an organization from the humiliation of being placed in the media spotlight and thus eroding the organizational reputation.

\subsection{Whistleblowing System}

An effective whistleblowing system would grant officials to feel safe enough to inform about malpractices (Fulcrum, 2012; Holtzhausen, 2016). It is a duty of the organization to create this feeling whereby they cannot simply ignore malpractices that they have witnessed. Providing a platform to officials to address the issue is by giving them a freedom of speech, protecting their rights, and at the same demanding loyalty from them for the sake of protecting the interests of stakeholders (Martin, 2010). These can be materialized by having an effective whistleblowing system (Kazan, 2009).

The whistle-blowing system provides a platform for employees to express their concerns in relation to malpractices which can prevent reprisals on whistle-blowers (Miller, 2015). The system should well-define issues of what can be reported and state a clear distinction between whistleblowing reports and personal grievances. The whistleblowing system is an important part of the organisational internal control because it boosts the establishment of a strong ethical and compliant culture. Internal controls are implemented to keep the organization on path toward profitability, operation efficiency and reduce surprises that come along the way (COSO, 2002).

As whistleblowing is a part of organizational internal control to reduce risk management, it is therefore important for any municipal council to have the system in place. The system would increase the likelihood that an official will whistle blow within the organization instead of to outsiders. Setting up a whistleblowing system in a municipal council will provide the official's perception that management supports whistleblowing.

\section{Methodology}

A hermeneutic phenomenology study was conducted to explore on how the public officials view and opine a whistleblowing system. The study also explored on what are the elements that should be constituted in the whistleblowing system model. The exploration is confined to perceiving, recalling, and thinking about the subject of interests. The hermeneutic phenomenology is a qualitative study that not only focuses on illuminating details but also trivial facets within experience that may be taken for granted in lives, with an objective of generating meaning and accomplishing a sense of understanding (Wilson \& Hutchinson, 1991).

\subsection{Data Collection}

Data were gathered via two methods which were in-depth interview and focus group discussions. The in-depth interviews were conducted with four top management namely director, deputy director, accountant and assistant accountant. Data collection through interviews is a better option when collecting data to analyse words rather than 
numbers (Bryman \& Bell, 2011). Each session took about 30 minutes. The participants were selected through purposive sampling and the number depended on the saturation of the data.

The focus group discussions (FGD) were carried out to gather participants from similar backgrounds or experiences. For the purpose of this study, fifteen focus group discussion sessions were performed. Each session consisted of four participants of similar background which took approximately 45 minutes. This method was carried out to the fact that the participants were homogeneity in nature by having similar position, age group, level of education and year of service. FGD is valuable in providing an insight of diverse opinions among different participants and thus enabling the accurate visualization of the findings.

Both in-depth interviews and FGDs were video recorded and audio taped with prior consent from the participants. All sessions were carried out in the Malay language. This principle does not anticipate any pattern of response whereby the participants are free to express their views. They were given careful and detailed clarifications; any ambiguity will be probed further and facilitated, leading to an in-depth analysis. The participants were guaranteed of confidentiality and anonymity.

\subsection{Research Design}

The study explored participants' views of the whistleblowing system. Unlike hypothesis driven or quantitative research, this study is qualitative in nature that focuses on opinions, thinking and in-depth experience of participants. The participants were asked open-ended questions and encouraged to answer without imposing any restriction by applying the grounded theory approach. For both methods, the first researcher started the session by introducing herself and thanking participants for their inclination to participate. Later, the researcher briefly clarified the participants of the study objectives. This session was aided by another fellow researcher. The session was initiated with a question: "What do you understand of a whistle blowing system?" The participants were encouraged to voice out their understanding on whistle blowing. Next, they were asked, "In your opinion, what elements should be constituted in a whistleblowing system?" The participants were requested to give examples if clarification was needed and extended it, if they like to explain their answers in detail.

\subsection{Data Analysis}

Both in-depth interviews and focus group discussions were transcribed in verbatim, prior to analyse the data. The participants were encouraged to speak up freely and interpretation of response patterns was formed during the data analysis. The researcher lifted and erased all personal and identical information to maintain confidentiality and anonymity. These were performed immediately after completion of each session, usually in the same day.

Initially, the researcher immersed in the research setting by familiarizing and involving herself with the data to experience contextual sentiment. The researcher would reminiscence on how the participants responded to the questions. By undertaking this, the researcher was able to capture the participants' facial and oral expressions together with their body actions. This is vital to attain the essence of the interviews and discussions. Moreover, this enhances deeper understanding of the actions and language that were uttered in words or inferred through actions.

The audio tapes and transcriptions were further analysed independently by the second researcher and deliberated until an agreement was derived. Excerpts from the interviews were transcribed and presented to two public officials of FGD and top management for validation. They were requested to propose changes if there were differences to the interpretation of data before they were confirmed to accurately reflect the interviews and FGDs. Significant texts were underlined, coded, recorded and mapped. The researchers then identified a thematic outline.

Data were analyzed by content analysis using Nvivo 14 to produce qualitative findings. Emergent themes from the interview and FGD were used for analyzing the participants' views and thinking of elements that constitute the model of a whistle blowing system. This software can be used to recognize patterns, relations and emergent themes of the narrative description of the participant's opinions and experiences. The codes created by the software were further deliberated with the aim to look for resemblances and differences among the collected data. Functions, actions, descriptions and contexts were then categorized under suitable classifications. According to Akerland (2005), it is critical to read and reread the data before matching between reason and judgement. The method of analysis was later proceeded from coding to clarification before deducing for inferences.

The findings produced by Nvivo were later triangulated with other main sources of evidence such as informal conversations, documentations and direct observation prior to report in narrative statements. Multiple sources of evidence were obtained to create the precision, authenticity and validity of data. The convergence of bountiful sources of evidence would further augment the understanding of the elements that constitute a model of the whistleblowing system. 


\subsection{Reliability of Data}

Narrative responses provided by a participant were reconfirmed with responses given by other participants. This is to ensure the reliability and consistency of data apart from probing deeper understanding and clarification.

\section{Findings}

\subsection{Profile of Participants}

Participants for in-depth interviews consisted of 4 officials in the rank of top management namely director, secretary, finance and administration managers. Meanwhile, participants for focus group discussions were sixty officials of similar designation. In total, there were sixty-four officials who participated in this study. The findings further indicated that 36 or $56.25 \%$ of participants were females, while 28 or $43.75 \%$ were males. In terms of age, the highest number of participants were within the age of $41-55$ years, followed by $25-40$ years and above 55 years represented by $12(18.75 \%), 44(68.75 \%)$ and $8(12.50 \%)$ officials respectively. Additionally, 32 participants or 50.0 $\%$ had diploma and the remaining 32 participants or $50.0 \%$ had a degree. Finally, about 16 participants or $25.00 \%$ had served the organisation of less than 10 years, 32 participants had service between 10 to 20 years, while the remaining 16 participants had service of less than 10 years.

\subsection{A Model of Whistleblowing System}

The objective of this study is to explore the participants' thinking and views on elements that constitute a model of whistleblowing system. Findings derived from emergent themes indicated that the whistleblowing system had four themes, ten sub-themes with thirty codes. The findings are depicted in Table 1.

Table 1. Code, sub-theme and theme

\begin{tabular}{|c|c|c|}
\hline Code & Sub-theme & Theme \\
\hline $\begin{array}{l}\text { The staff will more likely highlight any corruption } \\
\text { if the system ensures anonymity }\end{array}$ & \multirow[t]{4}{*}{ Anonymity and confidentiality } & \multirow[t]{6}{*}{$\begin{array}{l}\text { Whistle-blowers } \\
\text { protection }\end{array}$} \\
\hline $\begin{array}{l}\text { Many will come forward to whistle blow if their } \\
\text { identity is kept confidential }\end{array}$ & & \\
\hline If staff feel safe, it incites them to whistle blow & & \\
\hline Hide whistleblower identity & & \\
\hline $\begin{array}{l}\text { Whistle blower should be protected from reprisal } \\
\text { within organization }\end{array}$ & \multirow[t]{2}{*}{ Protection of the disclosure } & \\
\hline $\begin{array}{l}\text { The protection should also be extended to } \\
\text { individuals close to the whistle blowers such as } \\
\text { spouses and family }\end{array}$ & & \\
\hline $\begin{array}{l}\text { The protection should be documented. This is to } \\
\text { encourage staff to come forward and report without } \\
\text { fear. }\end{array}$ & \multirow[t]{3}{*}{$\begin{array}{l}\text { Documented policies on whistle } \\
\text { blowing }\end{array}$} & \multirow[t]{7}{*}{ Internal Policies } \\
\hline $\begin{array}{l}\text { The organization should have standard operating } \\
\text { procedures on whistle blowing. }\end{array}$ & & \\
\hline $\begin{array}{l}\text { The policies on whistle blowing should be } \\
\text { established, so that the staff would perceive that the } \\
\text { management is committed in supporting whistle } \\
\text { blowing. }\end{array}$ & & \\
\hline $\begin{array}{l}\text { Whistle blowing is a noble deed as only those who } \\
\text { have high integrity would be more likely to whistle } \\
\text { blow. }\end{array}$ & \multirow[t]{3}{*}{ Procedures on complaint } & \\
\hline $\begin{array}{l}\text { The organization should have standard operating } \\
\text { procedures on whistle blowing. }\end{array}$ & & \\
\hline $\begin{array}{l}\text { The policies on whistle blowing should be } \\
\text { established, so that the staff would perceive that the } \\
\text { management is committed in supporting whistle } \\
\text { blowing. }\end{array}$ & & \\
\hline Provide a hot line channel so that employees would & Reporting Channels & \\
\hline
\end{tabular}




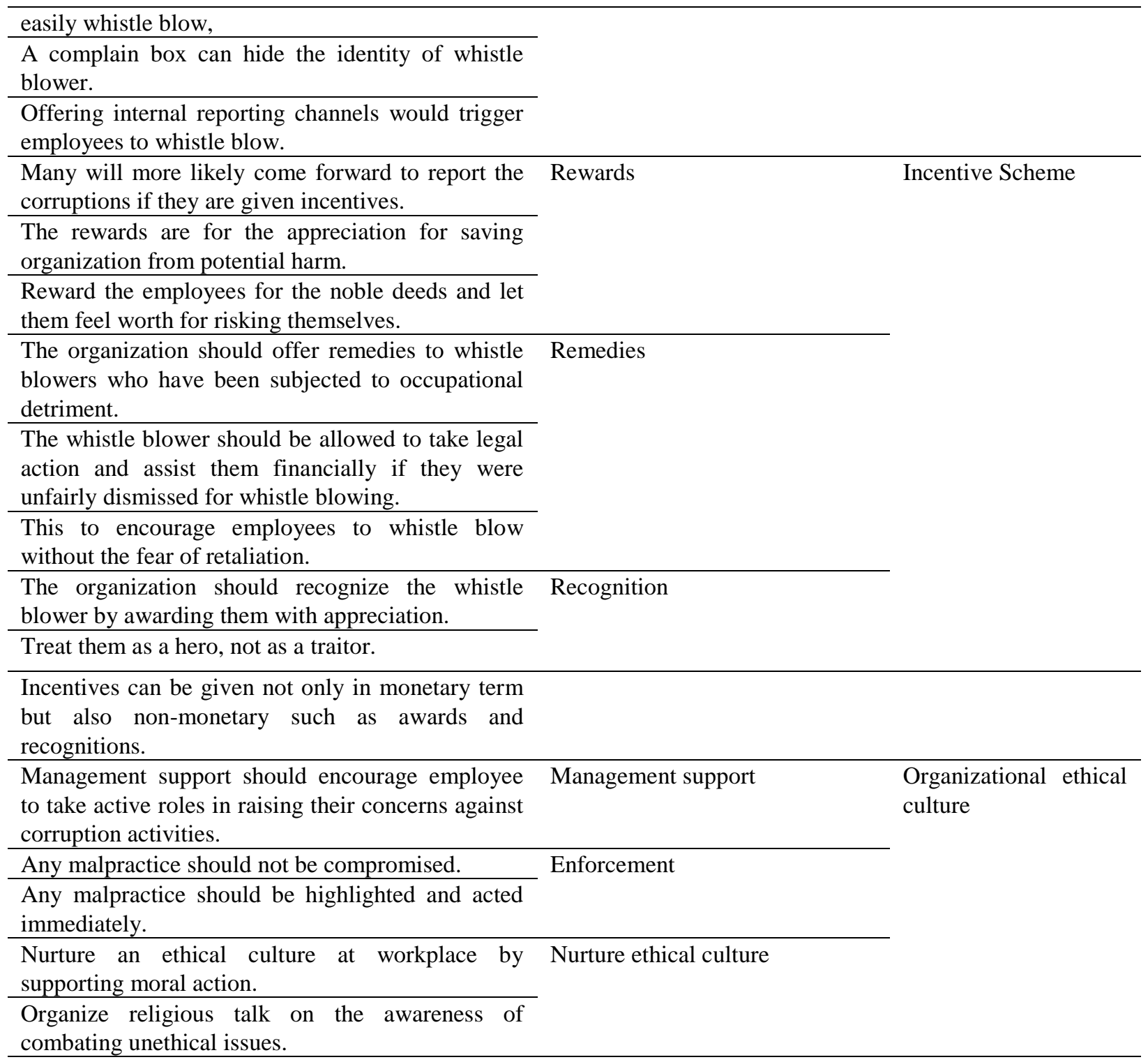

Below are the emergent themes derived from excerpt of interviews and focus group discussions of municipal council's top management and officials.

Theme 1. Whistleblowers Protection

The participants highly emphasized on the whistleblower's protections. These themes were manifested by two sub-themes that are anonymity and confidentiality as well as protection of the disclosure.

Sub-theme 1 . Anonymity and confidentiality

".....It is important that a whistleblower is guaranteed of anonymity and confidentiality, so that he or she can feel safe enough to report, knowing that nobody is aware of his or her action, and surely confident that he or she will not lose job due to the report"

(Municipal Council officer 3).

“....every effort should be taken to treat the whistleblower's identity with appropriate regard for confidentiality,...... the staff will feel safe to come forward and report....."

(Director)

Sub-theme 2: Protection of the disclosure

“....precisely, many employees are scared to report internally, because they fear of reprisal imposed by the superior who was involved. But, if they feel that we act seriously when they call or report, and even offer them protection, I'm of view that the number of reporting will escalate and become norms......."

(Administration manager) 
“... officials should be protected in all forms: retaliation, reprisal, harassment and from being victimize for reporting any malpractice incriminated by superiors......."

(Municipal council officer ...15)

Theme 2: Transparent Internal policies

The participants also stressed on the transparent of internal policies which was further divided into three sub-themes namely documented policies, procedures on complaint and reporting channels.

Sub-theme 1: Documented policies on whistleblowing

"..... we need a documented policy relating to what kind of malpractices that should be reported. The policy can be a reference, if any issue or dispute arises later......"

(Municipal council officer ......45)

“.......there should be well-defined types of issues that can be reported..., they do not have to include a definitive list, but could be a set of guidelines that can be followed, a clear distinction between whistleblowing reports and personal grievances. .... the policy should offer guidance and information on the process of reporting internally and externally".

(Municipal council officer .......33)

Sub-theme 2: Procedures on complaint

"the policy should describe the procedures in detail; this will provide a clear direction for employees, so that they will feel safe as they do no not violate any rules and act for the benefit of the organization.

(Municipal council officer

"a comprehensive set of procedures is essential that includes receipt of complaints, effective whistleblowing processes and specific individuals to channel the complaints who are independent from any hierarchy of command......".

(Municipal council officer.........30)

'investigation process should be fair, free from bias and all facets of the disclosure should be fully analysed, thoroughly investigated and resolved..."

(Municipal council officer ......22)

Sub-theme 3: Reporting channels

".. the organization should provide a platform so that the complaint can be channeled without revealing the identity of the informer. ..the channels should be in many forms, complain boxes, hotlines, audit committee that is comfortable to a whistleblower......".

(Municipal council officer

“......offering internal reporting channels would entice employees to whistle blow internally, instead of looking for external audiences".

(Secretary)

\section{Theme 3: Incentive Schemes}

Participants were of view that the whistleblowing will escalate if incentives are given for acknowledging their noble deeds. For them, incentives should be given in three forms which are rewards, remedies and recognitions.

Sub-theme 1: Rewards

"...the management should reward those who report malpractices by giving some monetary incentives, promotion....this is because it is extremely difficult to intrigue someone to disclose ....... which can save organization from potential harm".

(Municipal council officer ..... 32)

Sub-theme 2: Remedies

“...... whistleblower should be given remedy should anything happen to him .......this should be extended to individuals who are close to the whistleblower such as spouses and family members.....offering him a lawyer and legal assistance".

(Municipal council officer......21)

Sub-theme 3: Recognition

"Apart from monetary rewards, the whistleblower should be given recognition for their noble deeds such as excellent services award or other awards, because not many are willing to risk their life....celebrate them as heroes, as exemplary model, other staff will emulate their deeds".

(Municipal council officer......37) 
Theme 4 - Ethical culture

The last theme identified was ethical culture. This theme was further classified into three sub-themes that were management support, enforcement and nurture ethical culture.

(a). Management support

“.....top management should show its support by encouraging employees to blow the whistle, do not isolate them...the support should be written and transformed into documents and actions.

(Municipal council officer

(b) Enforcement

"...... any wrongdoing should not be compromised, it should be greatly highlighted and taken immediate action.... a separate unit within the municipal council should be set-up that deals with malpractices including whistleblowing...."

(Municipal council officer.

"There is a tendency that the staff makes allegations in bad faith because he may have vengeance with the management. Those who make these allegations should face disciplinary actions.

(Administration manager)

(c) Nurture ethical culture

“.... employees need to be trained and educated on the relevant whistleblowing legislation in Malaysia. They also need to be trained on the whistle blowing processes, policies and procedures, as well as the work ethical values."

(Director)

"Nurturing an ethical culture at workplace by supporting moral action.....any malpractice is intolerable, organizing religious talk on ethical values, remind them of the sins, the punishment, not only in this world but also in the hereafter".

(Municipal council officer......43)

\section{Discussion}

The objective of this study is to explore a model of whistleblowing system for a municipal council. From the interviews and focus group discussions, four themes were identified to be elements of a model for the whistleblowing system. The elements were whistle blower protection, internal policies, incentives and organizational ethical culture.

The first element is whistleblower protection with two sub-elements namely anonymity and confidentiality as well as protection of the disclosure. To promote whistleblowing, one should be assured of the anonymity and confidentiality of his/her identity. This is in tandem with International Federation of Accountant (IFAC) whistleblower policy (2019) that emphasizes on treating the whistleblower's identity with appropriate regard for confidentiality. The policy however insists that one should put his or her name to allegation for follow-up because an investigation may not be possible unless the source of information is identified.

The second sub-element stresses on whistleblowers' protection. The protection should also be extended to their close family members. With the protection in place, one would feel secured and safe and thus expedite him/her to confide with those who are in power about malpractices (Fulcrum, 2016). This is consistent with Bierstaker et al. (2006) and Oghu (2017) in which adequate protection granted to one would encourage him/her to come forward and whistle blow.

The second element is internal policy which is manifested by three sub-elements namely documented policy on whistleblowing, procedure on complaint and reporting channels. The policy should entail a clear statement of what, when, who and how should malpractices be stated. Apart from that, the policy should resonate with IFAC whistleblowing policy 2019 and Mekonnen and Sundh (2014) to entail a clear distinction between whistle blowing reports and personal grievances.

The second sub-element is procedure on complaint and investigation that narrates on how malpractices can be whistle blow either to internal or external audiences. The procedure should ease and accommodate internal whistleblowing and thus deter external whistleblowing which could be embarrassing to organization. Reporting channel is the third sub-element in which an appropriate platform such as hotlines or complaint boxes are created to expedite whistleblowing. These three sub-elements are related to internal policy of whistle blowing that is construed to the standard operating procedures.

The third element is incentives which are classified into three sub-elements namely rewards, remedies and recognitions. These monetary and non-monetary incentives are important to acknowledge the whistleblowers in 
risking their life for protecting the stakeholders' interests (Eaton \& Akers, 2007). The incentives will escalate the likelihood of internal whistle blowing as they exhibit the management's commitment. The findings concur with the Annual Report to Congress on the Dodd-Frank Whistleblower Program (2016) in the US that indicated the number of whistleblower tips received by the Security and Exchange Commission has grown more than 40 percent since 2012 after financial incentives were given to the whistleblowers.

Offering remedies or compensation to whistle blowers who have been subjected to occupational detriment for disclosing malpractices are aligned with those suggested by Clark (2013) and Mekonnen and Sundh (2014). If any of the whistle blower is unfairly dismissed, the system should allow them the opportunity to take legal action by taking their employer to court. Apart from monetary incentives, the whistleblowers should also be recognised with non-monetary incentives such as awarding them with medals and celebrating them as heroes or saviors for rescuing the organisation.

The fourth element identified is organizational ethical culture that is followed by three sub-elements namely support management, enforcement and nurture ethical climate. The support can be reflected through the establishment of the whistleblowing system (Callard \& Dehn, 2014). The enforcement, on the other hand, is imposed on the punishment in which perpetrators should face consequences regardless of their position status.

Finally, the third sub-element is nurture ethical culture. The findings construed with Zakaria et al. (2017) which accentuates officials to take active roles in raising concerns against malpractices. This can be achieved through nurturing an ethical culture at workplace by inculcating moral action to fight any malpractice. In addition, provide a space for employees to address the issue by giving him/her a freedom of speech to raise concern on the malpractices (Martin, 2010). The behaviour of top, middle and lower management should also be exemplary so that they portray good ethical conduct and set a good example to their employees.

\section{Management Implication}

The findings provide implications to the management of the elements to be considered in a model of whistleblowing system. The management should take a proactive approach in promoting whistleblowing by assuring officials on the protection, documented internal policies and by offering incentives as well as nurture organizational ethical culture. These elements should be formulated in a whistleblowing system and thus create a culture of openness and transparency that encourages officials to whistle blow.

\section{Academics Implication}

The findings contribute to the body of knowledge of a whistleblowing system model for a municipal council. The findings also provide an implication to academic fraternities on the importance of a proper system to be in place so that organisational malpractices will be eliminated.

\section{Limitation and Suggestion for Future Study}

This study only explores on a whistleblowing model specifically for a municipal council in Malaysian context. The findings might not be suitable to other organisations or nations as no one size fits all solutions. Future studies are suggested to extend the study to other organizations or nations. The differences or similarities in findings would be interesting to explore and thus enrich understanding on the model of whistleblowing system.

\section{Conclusion}

In a nutshell, the findings indicated that a model of the whistleblowing system for a municipal council consists of protections, internal policies, incentives and ethical culture. Having the whistleblowing system in place is expected to escalate the whistleblowing practices and thus alleviates malpractice incidences. The system would also increase the likelihood of internal whistleblowing and thus decrease the external whistleblowing, that will expose internal affairs to the public. Revealing the affairs would lead to embarrassment and erode the organisational reputation. Indeed, an effective whistle blowing system will lead to the transformation of the organisational culture towards integrity, accountability and transparency. This will reduce the risks of organisational failures that complement a sound corporate governance system. Eventually, it is expected that the whistleblowing system will elevate the municipal council's efficiency and thus enable to deliver services in a sustainable manner for the betterment of the community and nation.

\section{Acknowledgement}

The authors would like to express gratitude to the top management and officials of a Malaysian municipal council who participated in the study. The authors would also like to thank the Malaysian Ministry of Education and 
Research Management Centre of Universiti Teknologi MARA for their support in funding this research grant (FRGS/1/2018/SS01/UITM/02/20).

\section{References}

1MDB: Malaysia's extraordinary financial scandal. The Star Online, 18 December 2018. Retrieved from https://www.thestar.com.my/news/nation/2018/12/18/1 mdb-malaysias-extraordinary-financial-scandal

Ahmed, M. A., \& Koech, P. (2019). Influence of public governance on service delivery in Benadir Municipality. Somalia. International Journal of Academic Research, 1(2), 196-206. https://doi.org/10.32898/ihssj.02/1.2article15

Akerlind, G. (2005). Variation and commonality in phenomenographic research methods. Higher Education Research and Development, 24, 321-334

Alleyne, P., Marshall, D. W., \& Arthur, R. (2015). Exploring factors influencing whistle-blowing intentions among accountants in Barbados. Journal of Eastern Caribbean Studies, 38(1 \& 2), 35-62.

Annual Report to Congress on the Dodd-Frank Whistleblower Program U.S. Securities and Exchange Commission 2016. Retrieved from https://www.sec.gov/files/owb-annual-report-2016.pdf

Bierstaker, J. L., Brody, R. G., \& Pacini, C. (2006). Accountants' perceptions regarding fraud detection and prevention methods. Managerial Auditing Journal, 21, 520-535.

Bjorkelo, B., Einarsen, S., \& Matthiesen, S. B. (2010). Predicting proactive behavior at work: Exploring the role of personality as an antecedent of whistleblowing behavior. Journal of Occupational and Organizational Psychology, 83, 371-394.

Bryman, A., \& Bell, E. (2011). Business research methods (3rd ed.). Oxford: Oxford University Press.

Callard, R., \& Dehn, G. (2004). Whistleblowing around the world: law, culture and practice. London: Public Concern at Work (PCaW).

Chamunorwa, J. C. (2015). An exploration of whistle blowing in fighting corruption in the public sector in South Africa: A case of Stellenbosch municipality. Master degree thesis, Stellenbosch University. Retrieved from https://scholar.sun.ac.za

Combating corruption at council level. The Star Online, 17 June 2015. Retrieved from https://www.thestar.com.my/metro/community/2015/06/17/combating-corruption-at-council-level

Committee of Sponsoring Organizations of the Treadway Commission. (1992). Internal Control Integrated Framework (Coopers \& Lybrand).

Eaton, T. V., \& Akers, M. (2007). Whistleblowing and good governance. The CPA Journal, 7(6), 66-71.

Fulcrum, (2012). Best practices in whistleblower systems. Retrieved from http://.fulcrum,com/best_practices_whistleblower.htm

Global Economic Crime and Fraud Survey 2018: Malaysia Report Global. Retrieved from https://www.pwc.com/my/en/publications/2018-gecfs-malaysia.html

$\begin{array}{lllll}\text { Government } & \text { Transformation } & \text { Programme } & \text { (Malaysia). } & \text { Retrieved }\end{array}$ https://en.wikipedia.org/wiki/Government_Transformation_Programme_(Malaysia)

Holtzhausen, N. (2016). Whistleblowing and whistle blower protection in the South African public sector. Unpublished Doctoral Thesis. Pretoria: University of South Africa.

IFAC (International Federation of Accountants). Operations Policy, Whistleblower Policy, April 2019. Retrieved from https://www.ifac.org/system/files/uploads/Gov/IFAC-Whistleblower-Policy-April-2019.pdf

Introduction of the new Municipal Financial Sustainability Index from Ratings Afrika. Retrieved from http://www.midvaal.gov.za/images/pdf/Financial_sustainability_of_SA_municipalities_2017.pdfidvaal.gov.za/i mages/pdf/Financial_sustainability_of_SA_municipalities_2017.pdf

Kazan, F. (2009). Doing the right thing takes immense courage: Whistle-blowers face being fired and losing their jobs/and their families. The Star, 2 February, 3.

$\begin{array}{llll}\text { KPMG. } & \text { Fraud } & \text { Survey. } & \text { (2013). }\end{array}$ http://www.kpmg.com/MY/en/IssuesAndInsights/ArticlesPublications/Documents/2013/fraud-survey-report.pdf 
Martin, P. (2010). The status of whistleblowing in South Africa: Taking stock. Open democracy advice centre. Retrieved http://www.opendemocracy.org.za/wpcontent/uploads/2010/10/ODACWhistleblowingReport_web.pdf

Mekonnen, K., \& Sundh, R. (2014). To have or not to have a whistleblowing system. Master degree thesis. Sweden: UPPSALA University. Retrieved from http://www.diva-portal.se/smash/get/diva2:739886/FULLTEXT01.pdf

Mesmer-Magnus, J. R., \& Viswesvaran, C. (2005). Whistleblowing in organizations: An examination of correlates of whistleblowing intentions, actions, and retaliation. Journal of Business Ethics, 62, 277-297.

Miller, S., Roberts, P., \& Spence, E. (2015). Corruption and Anti-Corruption: An Applied Philosophical Approach. New Jersy: Pearson Prentice Hall.

Near, J., \& Miceli, M. (1995). Effective Whistle-blowing. Academy of Management Review, 20, 679-708.

Official Secret Act 1979. Malaysian Parliament.

Pittroff, E. (2013). Whistle-Blowing systems and legitimacy theory: A study of the motivation to implement whistle-blowing systems in German organizations. Journal of Business Ethics, 1-14.

$\begin{array}{lllll}\text { PwC Global } & \text { Crime } & \text { Survey. } & \text { (2014). } & \text { Retrieved }\end{array}$ http://www.pwc.com/gx/en/economic-crime-survey/perpetrator/catch-a-thief.jhtml

Ratings Afrika - Municipal Financial Stability Index 2017. Retrieved from http://www.midvaal.gov.za/index.php/component/k2/item/1090-ratings-afrika-municipal-financial-stability-inde $\mathrm{x}-2017$

Seifert, D. L., Sweeney, J. T., Joireman, J., \& Thornton, J. M. (2012). The influence of organizational justice on accountant whistleblowing (2010). Accounting, Organizations and Society, 35, 707-717.

Syed Mohd, S. K. (2014). Study on Factors Influencing Internal Auditors of GLC Companies to Whistle blow. Unpublished MBA dissertation, Universiti Teknologi MARA, Malaysia.

Whistleblowers Protection Act 2010 (Act 711). Malaysian Parliament.

White paper on Law on Whistleblowing Kathleen Clark. (2013). Retrieved from http://jkt.kpkt.gov.my/en/main.php?Content=vertsections\&SubVertSectionID=65\&VertSectionID=43\&CurLoc ation $=43 \&$ IID $=\&$ Page $=1$

Zakaria, M., Razak, S. N. A., \& Yusoff, M. S. A. (2017). The Theory of Planned Behavior as a framework for whistleblowing intention. Review of European Studies, 8(3), 221-235. 